\begin{tabular}{||l|l|l||}
\hline \multicolumn{2}{|c|}{ PublisherInfo } \\
\hline \hline PublisherName & $:$ & BioMed Central \\
\hline \hline PublisherLocation & $:$ & London \\
\hline \hline PublisherImprintName & $:$ & BioMed Central \\
\hline \hline
\end{tabular}

130591474-760XGenome BiologyGenome BiolLife SciencesAnimal Genetics and GenomicsHuman GeneticsPlant Genetics \& GenomicsMicrobial Genetics and GenomicsBioinformaticsEvolutionary BiologyBiomedical and Life Sciences11611291

CoverDate : 2000-12-

The Author(s)2000

\title{
Error-filled embryos
}

\begin{tabular}{||l|l|l||}
\hline \multicolumn{2}{|c|}{ ArticleInfo } \\
\hline \hline ArticleID & $:$ & 3811 \\
\hline \hline ArticleDOI & $:$ & $10.1186 /$ gb-spotlight-20001027-01 \\
\hline \hline ArticleCitationID & $:$ & spotlight-20001027-01 \\
\hline \hline ArticleSequenceNumber & $:$ & 248 \\
\hline \hline ArticleCategory & $:$ & Research news \\
\hline \hline ArticleFirstPage & $:$ & 1 \\
\hline \hline ArticleLastPage & $:$ & 2 \\
\hline \hline & & RegistrationDate : 2000-10-27 \\
ArticleHistory & $:$ & OnlineDate \\
\hline \hline ArticleCopyright & $:$ & BioMed Central Ltd2000-10-27 \\
\hline \hline ArticleGrants & $:$ & \\
\hline \hline ArticleContext & $:$ & 130591111 \\
\hline \hline
\end{tabular}




\section{William Wells}

Email: wells@biotext.com

Humans are incredibly inefficient when it comes to reproduction. Fertile couples have only a $25 \%$ chance of achieving a viable pregnancy per menstrual cycle. Now, in the November Molecular Human Reproduction, Wells and Delhanty suggest that the low success rate may be explained by the high incidence of chromosomal abnormalities in early embryos, many of which never reach the stage of implantation (Mol Hum Reprod 2000, 6:1055-1062). In previous research, fluorescent in-situ hybridization (FISH) methods that detect individual chromosomes were used to show that up to half of all embryos have abnormalities. FISH, however, can be reliably used for only a few chromosomes at a time. Therefore Wells and Delhanty combined whole genome amplification with comparative genomic hybridization to analyze all chromosomes of each cell of in-vitro fertilized (IVF) embryos. Of the 12 embryos analyzed (a total of 64 separate cells), nine had at least some aneuploid cells. Eight embryos were mosaic, containing different chromosome complements in different cells. The presence of three completely normal embryos was actually surprising given the high frequency of abnormalities detected with just a few FISH chromosome probes, but can be explained by the clustering of multiple aneuploidies in single cells. All the aneuploidy may arise from the lack of a mitotic checkpoint in early embryonic cells. To get around this deficiency, and improve the success rate of IVF, a simplified version of the current protocol could be used to analyze a single cell extracted from early embryos.

\section{References}

1. Molecular Human Reproduction, [http://molehr.oupjournals.org/]

2. Multicolour FISH detects frequent chromosomal mosaicism and chaotic division in normal preimplantation embryos from fertile patients.

This PDF file was created after publication. 